\title{
The optimization of hydraulic governor performance taking account of the grid inherent stability factor and elastic water hammer effects
}

\author{
Case of Pelton turbines (*) \\ BY G. RANSFORD WT J. ROTTNER \\ ENGINEERS AT THE SOGHEAM, GRENOHLE \\ Texte français, p. 38
}

The above is a sequel to the paper by Messrs. G. Ransford and P. Arnaud (La Houille Blanche, Nr. 3, 1958, p. 210) which dealt specifically with the Francis turbine case.

\begin{abstract}
The first part of the article deals with the governing of a Pelton turbine taking account of the elastic water hammer and the grid inherent stability factor. Within the stable zone, values of the integral typifying the accuracy of gowerning are determined (in a similar way to a previous treatment dealing with Francis tur-
\end{abstract}

bines). The results are given on six diagrams. In the second part of the article, a concrete case is analysed. In particular, the variation of speed of the machine after a load change is analysed, using the optimum governing parameters deternined by the preceding treatment.

\section{INTRODUCTION}

The difficult problem of analysing the governing of Pelton turbines, or generally speaking of high-head turbines, seems to have been tackled for the first time by D. Gaden [4] and subsequently by $J$. Daniel in his thesis [2]. Amongst those writing in French who have studied it since, M. Cuénod [1], G. Nasse [7] and Kuntzmann, Daniel and Ma $[6]$ can be mentioned.

We have thought it useful to take this subject up again for similar reasons to those invoked in " previous article [8] dealing with the governing of medium Francis turbines:

(i) Generally speaking, existing literature does not endeavour to treat simultaneously all factors afrecting the behaviour of a unit; in the case of Pelton turbines, the grid inherent stability factor is usually neglected.

(ii) Failing adequate methods of analysis, it has not been possible hitherto to make a general investigation of the optimum dosing of the component parts of a governor :

- the accelerometer and tachymeter; or :

- the (dashpot relaxation time/slope of the temporary restoring system cam) according to the type of construction used.

As in the case of Francis turbines, many empirical suggestions are to be found concerning the best choice of governor constants. This is

(") Enares: In the preceding article, published in the issue No. 3, 1958, page 210, 2nd column, fith line from the bottom, equation (10), please lead:

$$
\mathrm{I}=\frac{4 \mathrm{~B}+\mathrm{D}}{2 \mathrm{D}(\mathrm{BC}-\mathrm{D})} w_{i{ }^{2}}^{2} \quad \text { instead of } \mathrm{I}=\frac{4 \mathrm{~B}+\mathrm{D}}{2 \mathrm{D}(\mathrm{BC}-\mathrm{D})}
$$


not surprising, as it is difficult to see how an entirely satisfying result could be obtained withoui Krasovsky's theorem [8] or at least a comparable method of analysis.

The utility of this theorem can be judged from the results obtained here. The evaluation of the integral I (or of similar ones typifying the accuracy of governing) by other meansdirect calculation, analysis of Feldbaum [3] [5] - becomes impossible here, even if for the third order, these methods could be considered, though involving immense additional work. If Feldbaum's method is considered, the study of a servo-system described by an equation of the $n$ th. order involves amongst other things the solution of $n(n+1) / 2$ simultaneous algebric equations. Apart from the fact that in Krasovsky's method all factors used are given in explicit form, there are $n$ or $(n-1)$ algebric equations only to be solved according to whether the mechanism is one with permanent output droop or not. When an infinite set of equations, converging in the zone of stability, has to be dealt with, as in the case of finite retards or elastic water hammer, it can be appreciated that Krasovsky's analysis is the only feasible one.

\section{SYM BOLS}

The symbols used are the same as the previous article [8], the following being added :

$$
\begin{aligned}
& k_{1} k_{2} k_{3} k_{4}: \text { integration constants } \\
& p \quad \text { : complex number used in the Laplace transformation. } \\
& x \quad=\mathrm{X} / \mathrm{L} \text {. } \\
& x_{1} x_{2} x_{3} \ldots x_{n-1}: \text { solutions of the standard system of }(n-1) \text { simultaneous equations } \\
& \text { of Krasovsky. Here, } n=6 \text { and } 8 \text {. } \\
& \boldsymbol{J} \quad \text { : time taken for an elastic pressure surge to cover the distance } \mathrm{L} \\
& \text { between the turbine and the intake. } \\
& \mathrm{V}=\mathrm{V}_{n}+\Delta \mathrm{V} \text {. } \\
& V_{n} \quad \text { : flow velocity in the penstock at opening } n \text {. } \\
& \mathrm{X} \text { : distance up the penstock from the turbine. } \\
& \text { on : product of the elastic pressure wave velocity in the penstock and } \\
& \left.\left(\mathrm{Q}_{n} / 2 g \mathrm{HS}\right)=\mathrm{V}_{n} / 2 g \mathrm{H}\right) \text {. This will be written more simply when } \\
& \text { no confusion may result. } \\
& \varphi \quad=p / 2 \rho_{n} i \text {. }
\end{aligned}
$$

It is worth while recalling the meaning of certain parameters used previously:

$a=\frac{c_{n} f_{n}^{20}}{\tau} A:$ the inherent stability factor of the grid in dimensionless notation.

$c_{n}=\frac{r_{11}}{r_{n}} \quad$ : the reciprocal of relative efficiency.

$f_{n}=\frac{c_{n}}{\mathrm{Y}_{n}}$ : the relative power output.

$l=\frac{\mathrm{T}}{c f 0} \quad$ the dimensionless time variable $(\mathrm{T}=$ time in seconds).

$n=\frac{\tau}{c f^{2} 0} \frac{\Delta \Omega}{\Omega_{1}}$ : the runner speed variation in dimensonless notation.

$$
w_{0}=\frac{\Delta W}{W_{n}} \text { : the relative power demand variation. }
$$

$$
\mathrm{I}=\int_{0}^{\infty} u^{2} d t
$$




$$
\begin{aligned}
& \mathrm{K}_{\mu} \mathrm{K}_{\lambda} \quad \begin{array}{l}
\text { : governor constants (rapidity of response of the tachymeter and the } \\
\text { accelerometer respectively). }
\end{array} \\
& 0=\frac{\mathrm{Q}_{1}}{g \mathrm{H}_{1}} \Sigma \frac{\mathrm{L}}{\mathrm{S}} \\
& \tau \quad: \text { specific inertia for unit at maximum load. }
\end{aligned}
$$

Thick type will be used for Laplace transforms. The variables $h_{x} q_{x}$ denote the pressure and discharge variations at point $x$. At the turbine $(x=0)$, by definition $h_{x=0}=h$ and $q_{x=0}=q$.

\section{BASIC EQUATIONS OF A HYDROPOWER UNIT OPERATING ON AN ISOLATED ELECTRICAL NETWORK}

These equations, which we have already given in dimensionless form [8], will be briefly recalled here :

(1) Equation of rotation of the runner :

$$
\frac{d u}{d t}=q+h-w_{0}-a u
$$

(2) Equation giving the flow through the turbine :

$$
q=y+\frac{1}{2} h
$$

(3) Governor equation :

$$
\frac{d y}{d t}=-\mu u--\lambda \frac{d u}{d t}
$$

Note that :

(a) In equation (1), the variation of efficiency, which is negligible in Pelton turbines, is not taken account of.

(b) In equation (2), the orifice law applying accurately to Pelton units is used.

(c) In equation (3), the same governor equation as for Francis units has been used; in other words, we have not allowed for possible deflector action during large changes in power output. This equation is valid for small variations in speed or out- put only (it should be noted that the deflector is normally held in reserve some distance from the jet).

These three equations must now be written in terms of Laplace transforms. This amounts to multiplying by $e^{n t}$, and then integrating from 0 to $\infty$ with respect to $t$.

The following equations are thus obtained :

$$
\begin{gathered}
p \mathrm{u}=\mathrm{q}+\mathrm{h}-\left(w_{0} / p\right)-a \mathrm{u} \\
\mathrm{q}=\mathrm{y}+(1 / 2) \mathbf{h} \\
p \mathrm{y}=-\mu \mathrm{u}-\lambda p \mathbf{u}
\end{gathered}
$$

The term - $w_{0} / p$ expresses the effect of a sudden throwing on of load at time $t=0$.

The elimination of $u$ and $y$ gives the following result :

$\left\{p^{2}-(2 \lambda-a) p-2 \mu\right\} \mathbf{h}=2\left\{p^{2}+(a+\lambda) p+\mu\right\} \mathbf{q}$

$$
-\frac{2 u w_{0}(\mu+\lambda p)}{p}
$$

This expression will be availed of in studying the limiting stability conditions. When examining the behaviour of the servo-system within the stable zone, we shall however require an expression containing $\mathbf{u}$ after eliminating $\mathbf{q}, \mathbf{y}$ and $h$. This matter will be taken up again after deriving the elastic water hammer equation.

\section{THE ELASTIC WATER HAMMER EQUATION}

The standard method of analysis explained in greater detail in the articles mentioned in the reference list will be briefly outlined.
The basic equations :

$$
\frac{\partial \mathrm{V}_{x}}{\partial \mathrm{T}}=g \frac{\partial \mathrm{H}_{x}}{\partial \mathrm{X}} ; \quad \frac{\partial \mathrm{V}_{x}}{\partial \mathrm{X}}=\frac{g}{a^{2}} \frac{\partial \mathrm{H}_{z}}{\partial \mathrm{T}}
$$


can be written in terms of dimensionless variables as follows :

$\frac{\partial q_{x}}{\partial t}=\frac{c f^{0}}{2 \rho_{n} J} \frac{\partial x}{\partial h_{x}} ; \quad \frac{\partial q_{x}}{\partial x}=\frac{1}{2_{\vartheta_{n}} J c f \theta} \frac{\partial h_{x}}{\partial t}$

seeing that :

$$
\mathrm{V}=(1+q) \mathrm{V}_{n}
$$

It will be recalled that :

$$
t=\frac{\mathrm{T}}{c f \theta}
$$

and :

$$
c \rho=\frac{\mathrm{Q}_{n}}{g \mathrm{H}_{1}} \Sigma \frac{\mathrm{L}}{\mathrm{S}}
$$

Equations (9) may be transformed as follows :

$\frac{\partial^{2} q_{x}}{\partial x^{2}}=\left(\frac{\mathrm{J}}{c / 0}\right)^{2} \frac{\partial^{2} \phi_{x}}{\partial l^{2}} ; \quad \frac{\partial^{2} h}{\partial x^{2}}=\left(\frac{J}{c / 0}\right)^{2} \frac{\partial^{2} h_{x}}{\partial t^{2}}$

or :

$\frac{\partial^{2} q_{x}}{\partial x^{2}}=\frac{1}{4 x^{2}} \frac{\partial^{2} q^{2}}{\partial t^{2}} ; \quad \frac{\partial^{2} h_{x}}{\partial x^{2}}=\frac{1}{4 n^{2}} \frac{\partial^{2} h_{x}}{\partial t^{2}}(10)$

seeing that, by definition :

$$
\frac{J}{c f 0}=\frac{1}{2 q_{n}}
$$

Apply the Laplace transformation to (10); we find :

$$
\frac{d^{2} \mathrm{q}_{t}}{d x^{2}}=\frac{p^{2} \mathrm{q}_{r}}{4 \rho_{n}^{2}} ; \quad \frac{d^{2} \mathrm{~h}_{r}}{d x^{2}}=\frac{p^{2} \mathrm{~h}_{n}}{4 \rho_{n}^{2}}
$$

The solutions of these equations, taking into consideration the initial conditions at the instant when the sudden load change occurs, are as follows :

$$
\begin{aligned}
& \mathbf{q}_{w}=k_{1} e^{m x / 2 \rho_{n}+-k_{2} e^{-p x / 2 \rho_{n}}} \\
& \mathbf{h}_{n}=k_{3} e^{m x / 2 \rho_{n}}+k_{4} e^{-n x / 2 \rho_{n}}
\end{aligned}
$$

Equation (9) indicates that :

$$
k_{3}=2 \rho_{n} k_{1} ; \quad k_{k}=-2 \vartheta_{n} k_{2}
$$

On the other hand, the excess pressure is nil at the entrance to the penstock:

$$
h_{i l=1}=0
$$

At the turbine intake, we know by definition that :

$$
\begin{aligned}
& h_{x=0}=h \\
& q_{x=0}=q
\end{aligned}
$$

Finally, the following expressions are found for $h$ and $q$ :

$$
\begin{aligned}
& \mathrm{h}=2 e_{n} k_{1}\left\{1-e^{n / p_{n}}\right\} \\
& \mathrm{q}=k_{1}\left\{1+e^{m / p_{n}}\right\}
\end{aligned}
$$

that is

$$
\mathbf{h}=-2 \vartheta_{n} \mathbf{q} \operatorname{tgh}\left(p / 2 \vartheta_{n}\right)
$$

\section{DETERMINATION OF THE ZONE OF STABILITY}

Elimination of h from equations (7) and (11)gives :

$$
\left[\left\{p^{2}+(a+\lambda) p+\mu\right\}+\vartheta_{n}\left\{p^{2}-(2 \lambda-a) p-2 \mu\right\} \operatorname{tgh}\left(p / 2 p_{n}\right)\right] \mathrm{q}=-\left(b w_{0} / p\right)[\mu+\lambda p]
$$

The limits of stability are determined by the coefficient of $q$ :

This problem has been studied previously; we will not repeat the analysis in detail. In practice, the equation of the boundary of the zone of stability on the right-hand side can be found by substituting 2 in $i$ for $p$ in this coefficient equated to zero.

If we write? instead of $p_{n}$ for simplicity, the following equation is found :

$$
\begin{array}{r}
2 ?\left\{\frac{\varphi^{2}}{2}+\frac{\mu}{4 p^{2}}+\left(\lambda-\frac{a}{2}\right) \frac{i \rho}{2 \vartheta}\right) \operatorname{tg}=(\lambda+a) \frac{\varphi}{2 \rho} \\
+i\left(\varphi^{2}-\frac{\mu}{4 \varphi^{2}}\right)
\end{array}
$$

whence, by equating real and unreal parts, we ind :

$$
\begin{aligned}
& 2 ?\left\{\frac{p^{2}}{2}+\frac{\mu}{4 p^{2}}\right) \operatorname{tg} \varphi=(\lambda+a) \frac{\varphi}{2 \rho} \\
& \left(i-\frac{a}{2}\right) \operatorname{tg}=\left(v^{2}-\frac{\mu}{40^{2}}\right)
\end{aligned}
$$

The final formulae, in terms of the parameter are as follows:

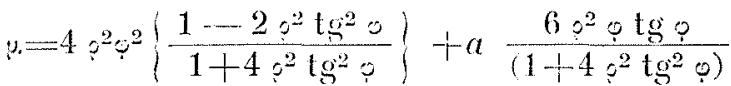

$$
\begin{aligned}
& \lambda=\frac{6 \rho^{2} \rho \operatorname{tg} \theta}{1+4 q^{2} \operatorname{tg}^{2} \theta}-a\left|\frac{1-2 \rho^{2} \operatorname{tg}^{2} \theta}{\mid 1+4 \rho^{2} \operatorname{tg}^{2} \varphi}\right|
\end{aligned}
$$


Daniel has given similar expressions in his thesis [2], but for the case $a=0$ only. For a fuller discussion, his study should be referred to.

The other boundary of the zone of stability is the $\lambda$ axis :

$$
\mu=0
$$

It will be observed that the period of the sustained oscillations defined by $\varphi$ is :

$$
\frac{2 \pi c f 0}{\ln \varphi}=\frac{\pi}{2 \varphi} \times 4 J \text { seconds }
$$

Here, $4 \mathrm{~J}$ is the natural period of the penstock. It can be checked that:

$$
\frac{\pi}{2 \varphi}>1 \text { ou } \varphi<1.57
$$

in all cases, as pointed out by Daniel [2].

\section{CRITERIA FOR THE ACCURACY OF GOVERNING OF A SERVO-SYSTEM IN THE EVENT OF A SUDDEN CHANGE IN LOAD}

We will not repeat here what has already been said about this in previous article [8]. It suffices to say that there are good reasons for prelerring the integral :

$$
\mathrm{I}=\int_{0}^{\infty} u t^{2} d t
$$

to all other criteria of governing accuracy. This is the integral of the square of the relative speed variation following on a sudden change of load.

In fact, seeing that the speed variation is proportional to $w_{0}$, the relative change in power, what is evaluated in actual fact is : $\mathrm{I} / w_{0}{ }^{2}$.

The optimum sovernor characteristics correspond, roughly speaking, to the least value of $\mathrm{I} / w_{0}{ }^{2}$.

\section{APPLICATION OF THE KRASOVSKY THEOREM}

The application of the theorem requires that a Laplace transform equation for u be expressed in terms of $w_{0}$, the variables $\mathbf{q}, \mathbf{y}$ and $\mathbf{h}$ being eliminated.

The following equation is thus obtained :

$$
\left\{\left[p^{2}+(a+\lambda) p+\mu\right]+\left[p^{2}-(2 \lambda-a) p-2 \mu\right] \rho \operatorname{tgh}(p / 2 \rho)\right\} \mathrm{u}=-w_{0}\{1+\rho \operatorname{tgh}(p / 2 \rho)\}
$$

As is to be expected, the factor multiplying $\mathbf{u}$ is identical with that multiplying $q$ in equation (12); as has been pointed out already, this factor determines the limits of stability of the servosystem as a whole.

The series for the hyperbolic tangent cannot be used here, on account of the convergence problem for small $\rho$. We multiply throughout by $\cosh (p / 2$,$) instead, and this gives the following$ result :

$$
\begin{aligned}
&\left\{\left[p^{2}+(a+\lambda) p+\mu\right] \cosh (p / 2 \rho)+\left[p^{2}-(2 \lambda-\alpha) p-2 \mu\right] \rho \sinh (p / 2 \vartheta)\right\} \mathbf{u} \\
&=-w_{0}\{\cosh (p / 2 \wp)+\rho \sinh (p / 2 \rho)\}
\end{aligned}
$$


The series expansion gives a succession of terms; those occurring on the left hand side in the factor multiplying $u$ are now given :

Constant term : $\mu$.

$$
\begin{aligned}
& p: a+\lambda-\mu \\
& p^{2}: 1+\frac{\mu}{S q^{2}}-\lambda+\frac{a}{2} \\
& p^{3}: \frac{a+\lambda}{8 \rho^{2}}+\frac{1}{2}-\frac{\mu}{24 \rho^{2}} \\
& p^{4}: \frac{1}{8 p^{2}}+\frac{\mu}{384 p^{4}}-\frac{[\lambda-(a / 2)]}{24 p^{2}} \\
& p^{5}: \frac{a+\lambda}{384 p^{4}}+\frac{1}{48 p^{2}} \quad-\frac{\psi}{1920 \varphi^{4}} \\
& p^{6}: \frac{1}{384} \rho^{-4} \quad+\frac{\mu}{46080 \rho^{6}}-\frac{[\lambda-(a / 2)]}{1920 \rho^{4}} \\
& p^{i}: \frac{a+\lambda}{46080 q^{i}}+\frac{1}{3840 p^{4}} \\
& p^{8}: \frac{1}{46080 e^{6}} \sqrt{+-}-
\end{aligned}
$$

and so on. In fact, two approximations have been considered :

(i) In the first case, the terms of higher order than $(p / 2 \varphi)^{4}$ have been neglected in the series expansion; this amounts to going no further than the first dotted line in

the foregoing table, and the approximation gives rise to a sixth order differential equation.

(ii) The second case includes terms up to $(p / 2 \rho)^{6}$; all coefficients displayed in the table are kept. The problem corresponds to solving an eighth order differential equation.

The same procedure applied to the coeficient of $-w_{0}$ gives the following result :

Constant term : 1

$$
\begin{aligned}
& p: \frac{1}{2} \\
& p^{2}: \frac{1}{8 \xi^{2}} \\
& p^{3}: \frac{1}{48 q^{2}} \\
& p^{4}: \frac{1}{384 q^{4}} \\
& p^{5}: \frac{1}{3840 q^{4}} \\
& p^{6}: \frac{1}{46080 \vartheta^{6}}
\end{aligned}
$$

and so on.

The theorem then gives the following result :

$$
\frac{\mathrm{I}}{w_{0}{ }^{2}} \cong \frac{1}{2 \mu}\left\{x_{1}+\frac{\rho^{2}-1}{4 \rho^{2}} x_{2}+--\frac{1}{\left[46080 \rho^{6}\right]^{2}} x_{7}\right\}
$$

for the eighth order approximation.

The formula for the sixth order one is even simpler :

$$
\frac{\mathrm{I}}{w_{0}{ }^{2}} \cong \frac{1}{2}\left\{x_{1}^{\prime}+\frac{\rho^{2}-1}{4 \rho^{2}} x_{2}^{\prime}+-\frac{1}{\left(384 \rho^{4}\right)^{2}} x^{\prime}\right\}
$$

Here, the $x_{1}^{\prime}, x_{2}^{\prime}, x_{5}^{\prime}$ are almost the same as the $x_{1}, x_{2},-x_{5}$ in the preceding case; the system of simultaneous equations of which they are the solutions is of the fifth order, instead of the seventh.

\section{CALCULATIONS ON DIGITAL COMPUTER}

We have carried out complete calculations for the sixth order approximation for the cases noted below :

$$
\begin{aligned}
& a=0 \quad o=1 \\
& a=0.2 \quad p=1 \\
& a=0 \quad \text { १ }=0.5
\end{aligned}
$$

$$
\begin{array}{ll}
a=0.2 & ?=0.5 \\
a=0 & ?=0.25 \\
a=0.2 & ?=0.25
\end{array}
$$

The results are given on the accompanying diagrams (p. 32). Note that the limiting cases: 


$$
\begin{array}{ll}
a=0 & \rho=\infty \\
a=0.2 & \rho=\infty
\end{array}
$$

have already been studied in the preceding article (8) under the headings:

$$
\begin{array}{ll}
a=0 & b=0 \\
a=0.2 & b=0
\end{array}
$$

The sixth order approximation is quite sufficient even for $0=0.25$, as comparisons with the eighth order one have shown. Thus, for example, we have studied four typical cases :

$\left.1^{\circ}\right) \quad a=0 ; \quad \circ=1 ; \quad \lambda=0.6 ; \quad \mu=0.1$

The sixth order approximation, i.e. that in which terms beyond $(p / 2 p)^{4}$ are neglected in the series expansions gives:

$$
\mathrm{I}=15.355 \mathrm{wo}_{0}^{2}
$$

whereas the eighth order one, in which terms up to $(p / 2 \rho)^{6}$ are kept, gives :

$$
\mathrm{I}=15.362 w_{0}^{2}
$$

$\left.2^{\circ}\right) \quad a=0.2 ; \quad \rho=1 ; \quad \lambda=0.3 ; \quad \mu=0.1$

- 6th order approximation : $\mathrm{I}=15.450 \mathrm{w}_{0}{ }^{2}$

- 8th order approximation : $\mathrm{I}=15.451 w_{0}{ }^{2}$

$\left.3^{\circ}\right) \quad a=0 ; \quad \circ=0.25 ; \lambda=0.3 ; \quad \mu=0.05$

- 6th order approximation : $\mathrm{I}=55.905 \mathrm{w}_{0}{ }^{2}$

- 8th order approximation : $I=56.150 w_{0}^{2}$

$\left.4^{\circ}\right) \quad a=0.2 ; \quad \rho=0.25 ; \quad \lambda=0.3 ; \quad \mu=0.05$

- 6th order approximation : $\mathrm{I}=38.468 w_{0}^{2}$

- 8th order approximation : $\mathrm{I}=38.492 w_{0}{ }^{2}$

\section{Discussion of results :}

On the six diagrams giving $\mathrm{I} / w_{0}{ }^{2}$, we have also noted the values pertaining to the frontier of the zone of stability. It should be recalled that the period of the sustained oscillations in this case is :

$$
\frac{2 \pi c f \theta}{\rho 0} \text { seconds }
$$

The influence of the grid inherent stability factor is considerable; as in the case of Francis turbines, it is wrong to neglect this. Here also, it is advisable to choose a point somewhat lower down than, and on the left of, the "eye" of the diagram. For the case $a=0,0=1$ for example, the least value of $I$ is located at :

$$
\mu=0.11
$$

$\lambda=0.65$

In point of fact, it would be preferable to choose :

$$
\begin{aligned}
& \mu=0.10 \\
& \lambda=0.62
\end{aligned}
$$

\section{Numerical example :}

A double-runner, double-jet Pelton turbine of 13,500 metric horsepower is supplied under a head of 347 metres. The maximum discharge is 3.27 cubic metres/second and $\mathrm{\Sigma LV}$ in metric units equals 2,480; the $\theta$ of the penstock is 0.73 seconds.

On the other hand, the inertia of the unit is 70 metric tons-metre ${ }^{2}$ (note that this is four times the British definition). The running speed being $500 \mathrm{r} . \mathrm{p.m}$., the specific inertia of the unit works out at :

$$
\tau=\frac{70 \times(500)^{2}}{270 \times 13500}=4.8 \text { seconds }
$$

The velocity of propagation of water hammer waves is taken as 1000 metres/sec. The velocity of flow in the penstock at full load being 3.92 mètres/second, we find

$$
\rho_{1}=0.576
$$

The unit being considered supplies a noninterconnected network. It is desired to know what speed variation will result from a sudden load increase when the turbine is running at $80 \%$ of full load. It can be supposed that the governor is constructed so as to ensure at each opening (and thus for each on the best combination of (tachymeter/accelerometer) elements or of (slope of temporary restoring cam/dashpot relaxation time). The grid inherent stability factor may be taken as equal to 1.5 , a reasonable value.

The efficiency is little affected by the opening; however, the efficiency at $80 \%$ exceeds that at full opening by $0.5 \%$

We thus find :

$$
\begin{aligned}
& c_{0.80}=0.995 \\
& f_{0.80}=0.80 \\
& a=\frac{0.995 \times(0,80)^{2} \times 0.73}{4.8} 1,5=0.145 \\
& \rho_{0.80}=0.458 .
\end{aligned}
$$

Interpolation in our diagram suggests as suitable values : 


$$
\begin{aligned}
& \mu=0.11 \\
& \lambda=0.50
\end{aligned}
$$

giving : $\quad K_{j}=\frac{4.8}{0.995 \times(0.80)^{2} \times(0.73)^{2}} 0.11=1.56 \mathrm{sec}^{-1} \quad \mathrm{~K}_{\lambda}=\frac{4.8}{0.80 \times 0.73} 0.50=4.1$

In a governor of the temporary restoring system type, these values correspond to a slope of cam equal to :

$$
\frac{1}{\mathrm{~K}_{\lambda}}=\frac{1}{4.1}
$$

and a dash-pot stiffness time of : $\frac{K_{\lambda}}{K_{\mu}}=\frac{4.1}{1.56}=2.64$ seconds

The differential equation (6th order approximation) may be written in terms of the Laplace transform as follows :

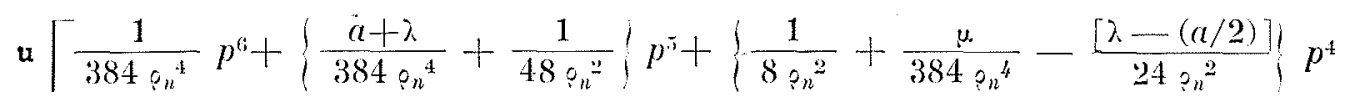

$$
\begin{aligned}
& +\left\{\frac{a+\lambda}{8 \rho_{n}^{2}}+\frac{1}{2}-\frac{\mu}{24 \rho_{n}^{2}}\right\} p^{3}+\left\{1+\frac{\mu}{8 \rho_{n}^{2}}-\lambda+\frac{a}{2}, p^{2}+\{a+\lambda-\mu\} p+\mu\right]= \\
& -w_{0}\left\{\frac{1}{384 \rho_{n}^{4}} p^{4}+\frac{1}{48 \rho_{n}^{2}} p^{3}+\frac{1}{8 \rho_{n}^{2}} p^{2}+\frac{1}{2} p+1\right\}
\end{aligned}
$$

Replacing the different parameters by their numerical values gives the following result: $\mathbf{u}=\left[p^{6}+2.3231 p^{5}+8.7439 p^{4}+14.5733 p^{3}+10.7807 p^{2}+9.0396 p+1.8586\right]$

$$
=-w_{0}\left(p^{4}+1.6781 p^{3}+10.069 p^{2}+8.4482 p+16.896\right)
$$

The Dandelin-Graeffe method can be used for finding the roots of the polynomial on the lefthand side. This consists in forming sucessively equations having roots equal to the second, fourth, eighth ...powers and so on of the original ones. The differences between the new roots become sufficient for it to be possible to neglect the small ones as compared with the big ones. Here, the equation of the 32nd. powers proves adequate.

Let $\mathrm{X}=p^{32}$ be the $32 \mathrm{nd}$. power of one of the roots of the left-hand side : $\mathrm{X}^{6}+1343.3110^{10} \mathrm{X}^{5}+904510^{22} \mathrm{X}^{4}-1263.2210^{28} \mathrm{X}^{3}-9658.2710^{25} \mathrm{X}^{2}$

$$
-1.466 .5110^{2+4} \mathrm{X}+4108.9710^{5}=0 \text {. }
$$
solving :

This equation has two real roots and two pairs of conjugate complex ones, obtained by

$$
\begin{gathered}
\mathrm{X}^{2}+1343.3110^{10} \mathrm{X}+904510^{22}=0 \\
904510^{22} \mathrm{X}-1263.2210^{28}=0 \\
1263.2210^{28} \mathrm{X}^{2}+9658.2710^{25} \mathrm{X}+1466.5110^{2+4}=0 \\
-1466.5110^{2-4} \mathrm{X}+4108.9710^{5}=0
\end{gathered}
$$

The real roots are immediately found to be :

$$
\begin{array}{ll}
\mathrm{X}=139659 & \text { and } \mathrm{X}=2.8018710-19 \\
p=-1.448 & \text { and } p=-0.26316
\end{array}
$$

The evaluation of conjugate complex roots may be done on following basis :

$$
\begin{aligned}
& \text { - sum of roots of the original equation }=-2.32311 \\
& \text { - sum of reciprocals of roots of the original equation }=-9.03955 / 1.8586 \\
& \text { - square of the modulus of the first pair }=\sqrt[32]{904510^{22}} \\
& \text { - square of the modulus of the second pair }=\sqrt[3]{1466.5110^{24} / 1263.22} 10^{28}
\end{aligned}
$$


The final result is as follows:

$$
\begin{aligned}
& y=-0.18724+2.5374 i \\
& p=-0.11874 \pm 0.8598 i
\end{aligned}
$$

The rational fraction giving u $(p)$ must now be broken up into its constituent partial fractions, in the following form:

$$
\mathrm{u}=\frac{\mathrm{A}}{p+1.448}+\frac{\mathrm{B}}{p+0.26316}+\frac{\mathrm{C} \pm \mathrm{D} i}{p+0.18724 \pm 2.5374 i}+\frac{\mathrm{E} \pm \mathrm{F} i}{p+0.11874 \pm 0.8598 i}
$$

The evaluation of $\mathrm{A}, \mathrm{B}, \mathrm{C}, \mathrm{D}, \mathrm{E}$ and $\mathrm{F}$ is rather tedious; the result is as follows :

$$
\mathbf{u}=w_{0}\left[\frac{1.052}{p+1.448}-\frac{2.644}{p+0.26316}+\frac{0.2337 \pm 0.45026 i}{p+0.18724 \pm 2.5374 i}+\frac{0.5623 \pm 0.13749 i}{p+0.11874 \pm 0.8598 i}\right\rceil
$$

Retransforming from $u$ to $u$ gives finally :

$u / w_{0}=1.052 e^{-1.448 t}-2.644 e^{-0.26316 t}+1.0146 e^{-0.18724 t} \sin \left(145 t^{\circ}+27.4^{\circ}\right)$

$$
+1.1577 e^{-0.1187 t t} \cos \left(49.25 t^{\circ}+13.7^{\circ}\right)
$$

Figure (1) shows how $u / \hat{w}_{0}$ varies with time. The $u^{2}(t) / w_{0}{ }^{2}$ curve has been drawn in too.

A rapid graphical integration gives :

$$
\mathrm{I}=\int_{0}^{\infty} u^{2} d t=13.97 w_{0}^{2}
$$

whereas the theorem used previously leads to :

$$
\mathrm{I}=13.73 w_{0}^{2}
$$

This is a good check on our calculations.

The lowest harmonic has a period of 7.3 in dimensionless form as can be seen from the equation for $u(t)$. This is roughly the abscissa of the point A where $u(t)$ becomes zero for the first time.

The greatest departure of $u(t)$, occurring at point $B$, is :

$$
u_{m}=2.46 w_{0}
$$

or, in the practical example we are concerned with :

$$
\begin{aligned}
\Delta \Omega & =\left\{\frac{0.995 \times(0.80)^{2} \times 0.73}{4.8}\right\} 2.46 w_{0} \Omega_{1} \\
& =0.238 w_{0} \Omega_{1} .
\end{aligned}
$$

Thus, a sudden increase of $5 \%$ in the power demand (i.e. from $80 \%$ to $84 \%$ of that at full opening) will give rise to a maximum frequency drop of 0.6 cycles, on a 50 cycle net- work. This variation is reached after :

$$
\begin{aligned}
\mathrm{T} & =0.995 \times 0.80 \times 0.73 \times 1.75 \\
& =1 \text { second, approximately }
\end{aligned}
$$

It would be evidently of much interest to try and evaluate approximately the maximum frequency variation directly from our diagrams, knowing $I$ and $\varphi$ only.

Seeing that, in dimensionless variables, the period of sustained oscillations on the boundary of the stable zone is given by $2 \pi / 0$ there is some reason for hoping that a formula similar to that used for Francis turbines [8] could be found, i.e. one similar to :

$$
\begin{aligned}
u_{\max } & =\beta \sqrt{\mathrm{I} / t_{u}} \\
& =\beta \sqrt{2 \% \mathrm{l} / \pi}
\end{aligned}
$$

In the present case, o would have to be taken as equal to :

$$
1.51
$$

if we desire to have $\beta=1$. This is roughly twice the value $\varphi=0.80$ corresponding to $\lambda=0.50$ on the boundary of stability for $a=0.145$, $p=0.458$; equation (14) enables a check to be made on this value found originally by interpolation in our diagrams. It would be evidently of much interest to study $\beta$ as a function of ? for the value of $\lambda$ chosen for the governor. 


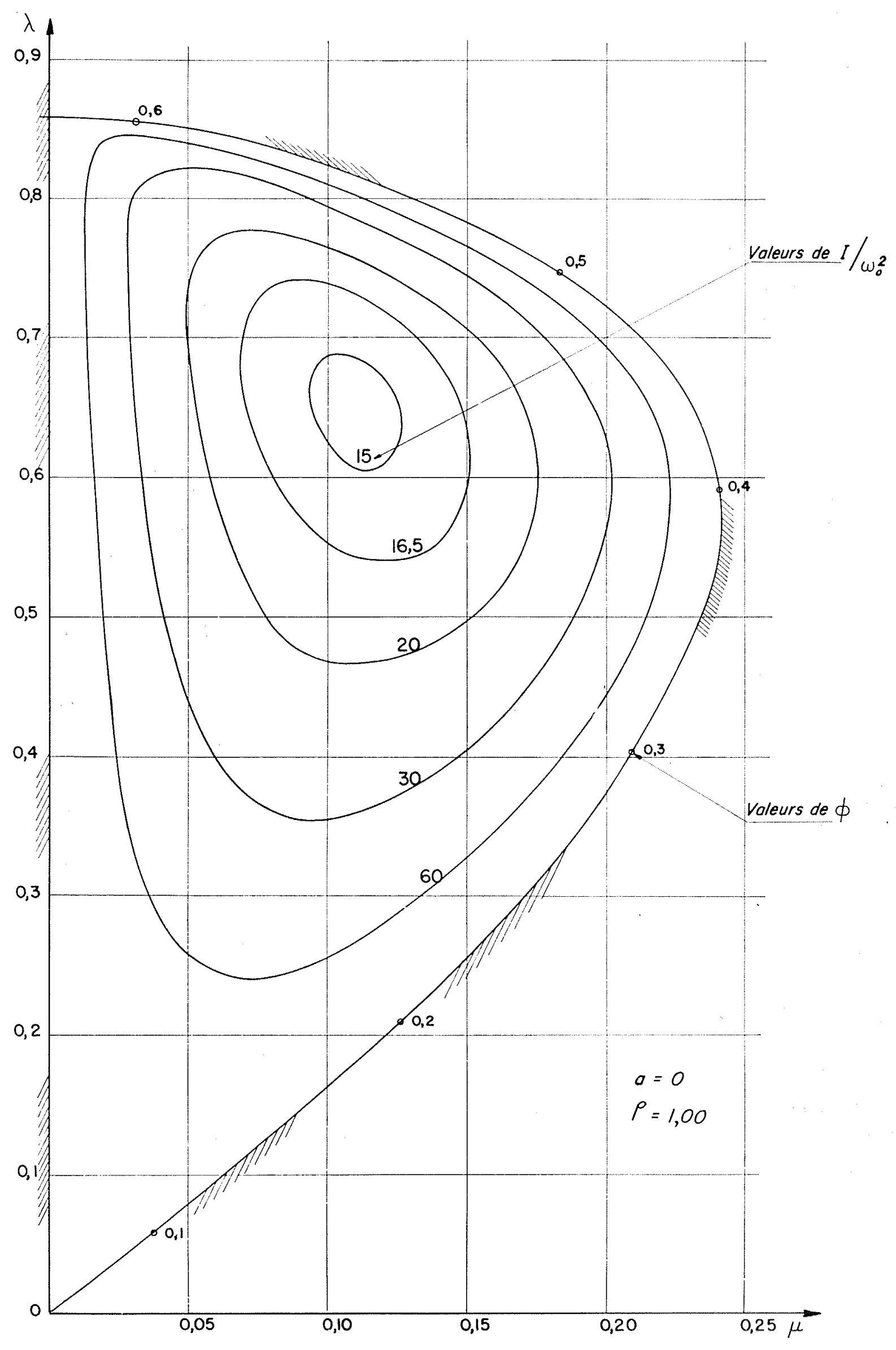

FIG. 1 


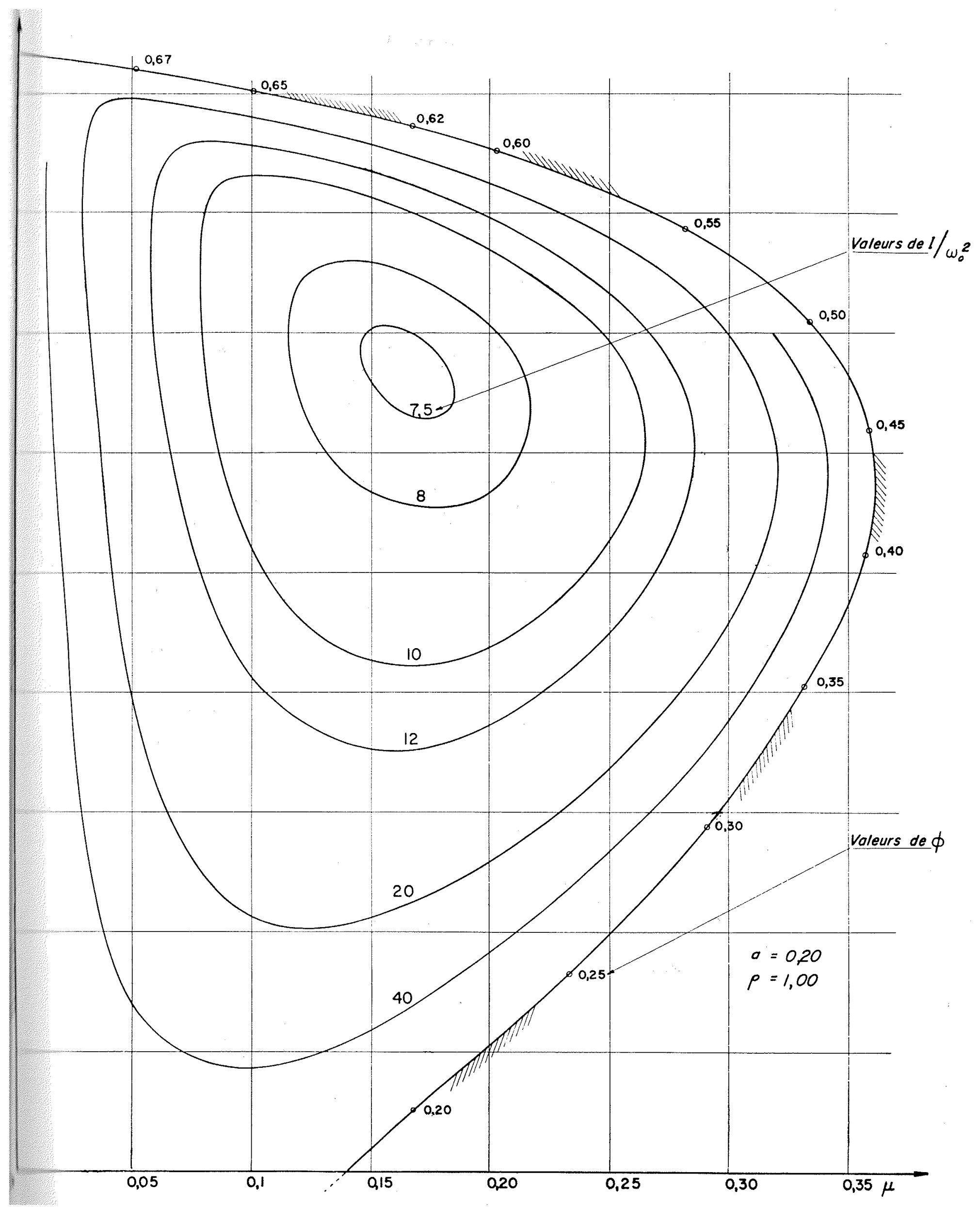




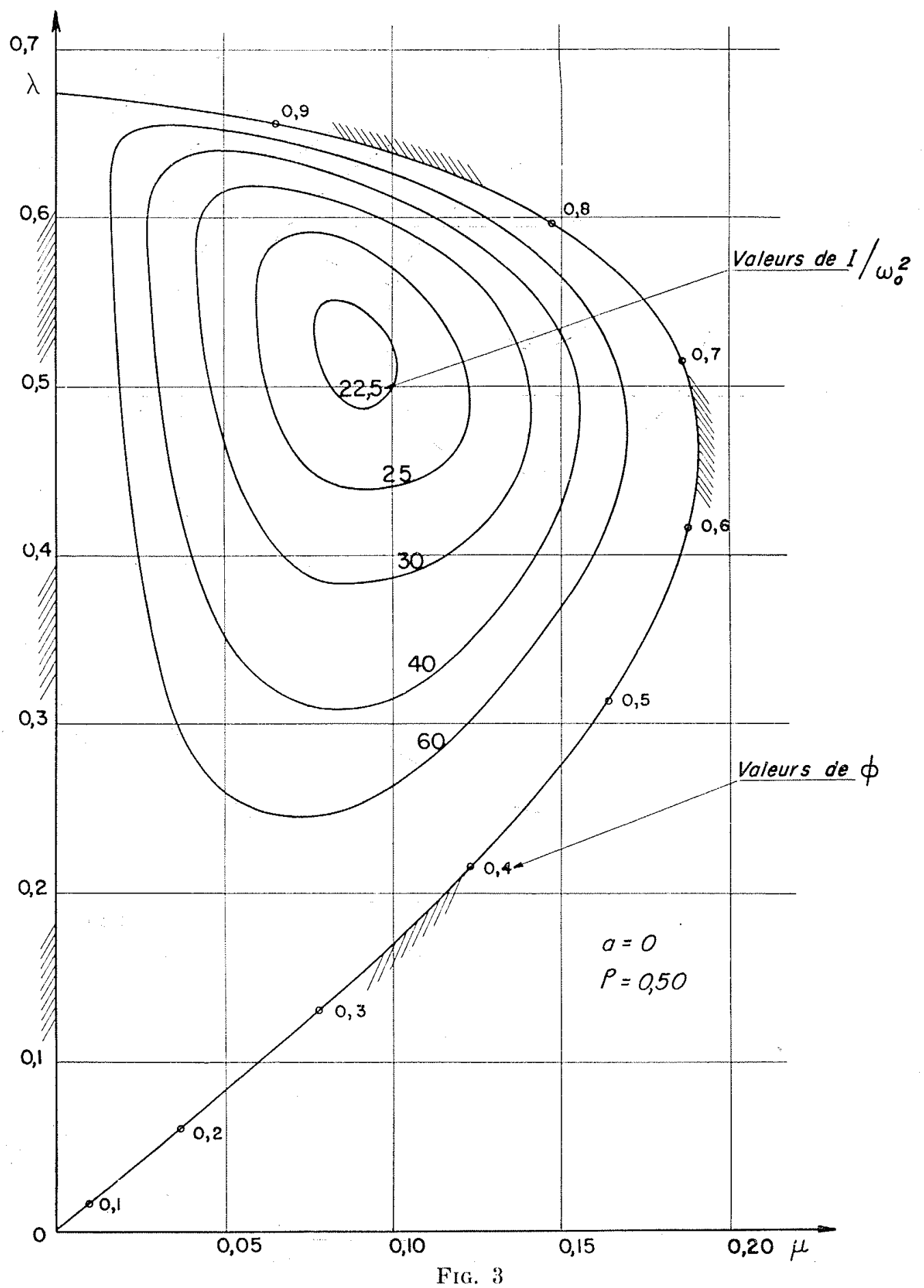




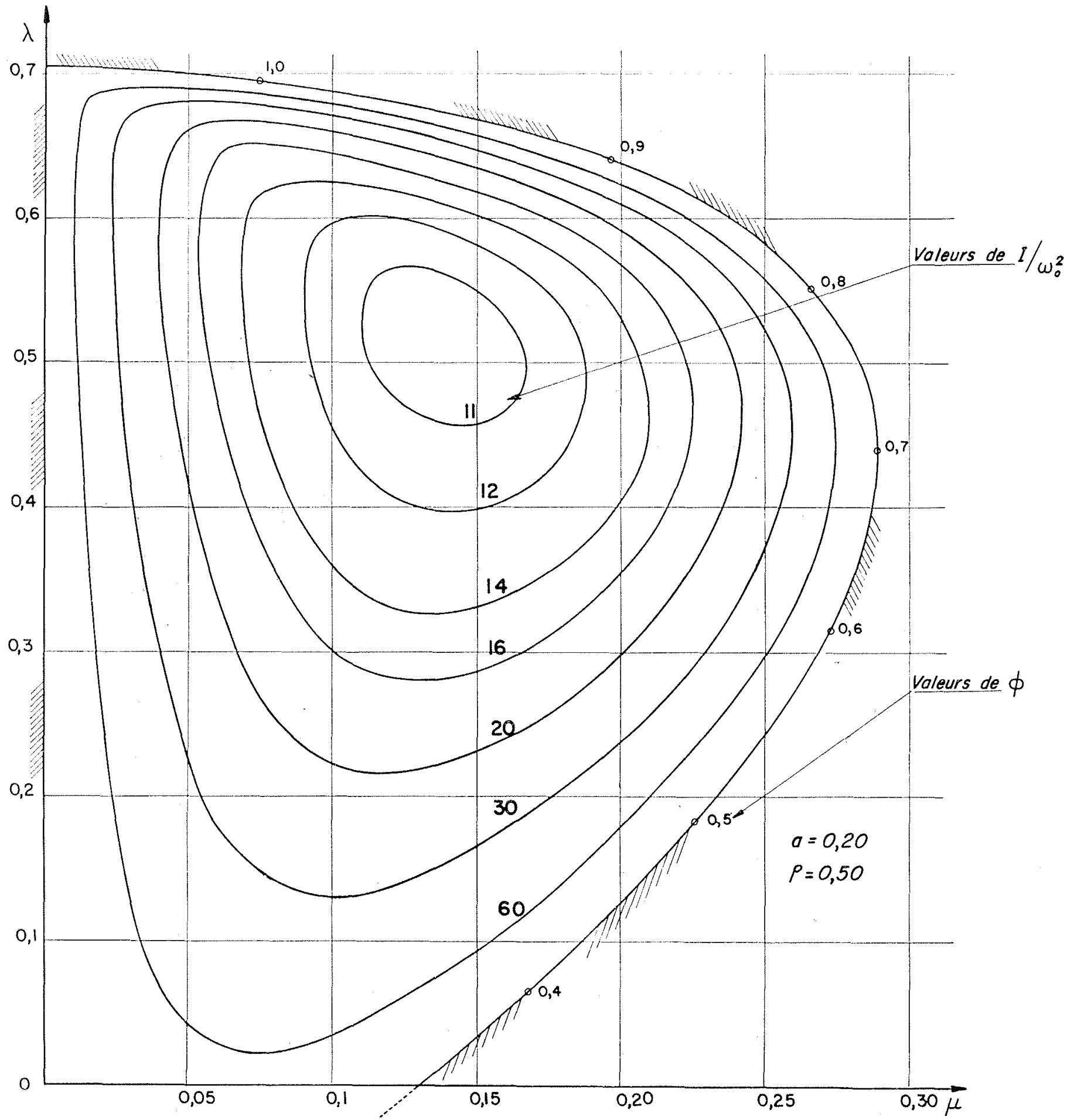

FIG. 4 


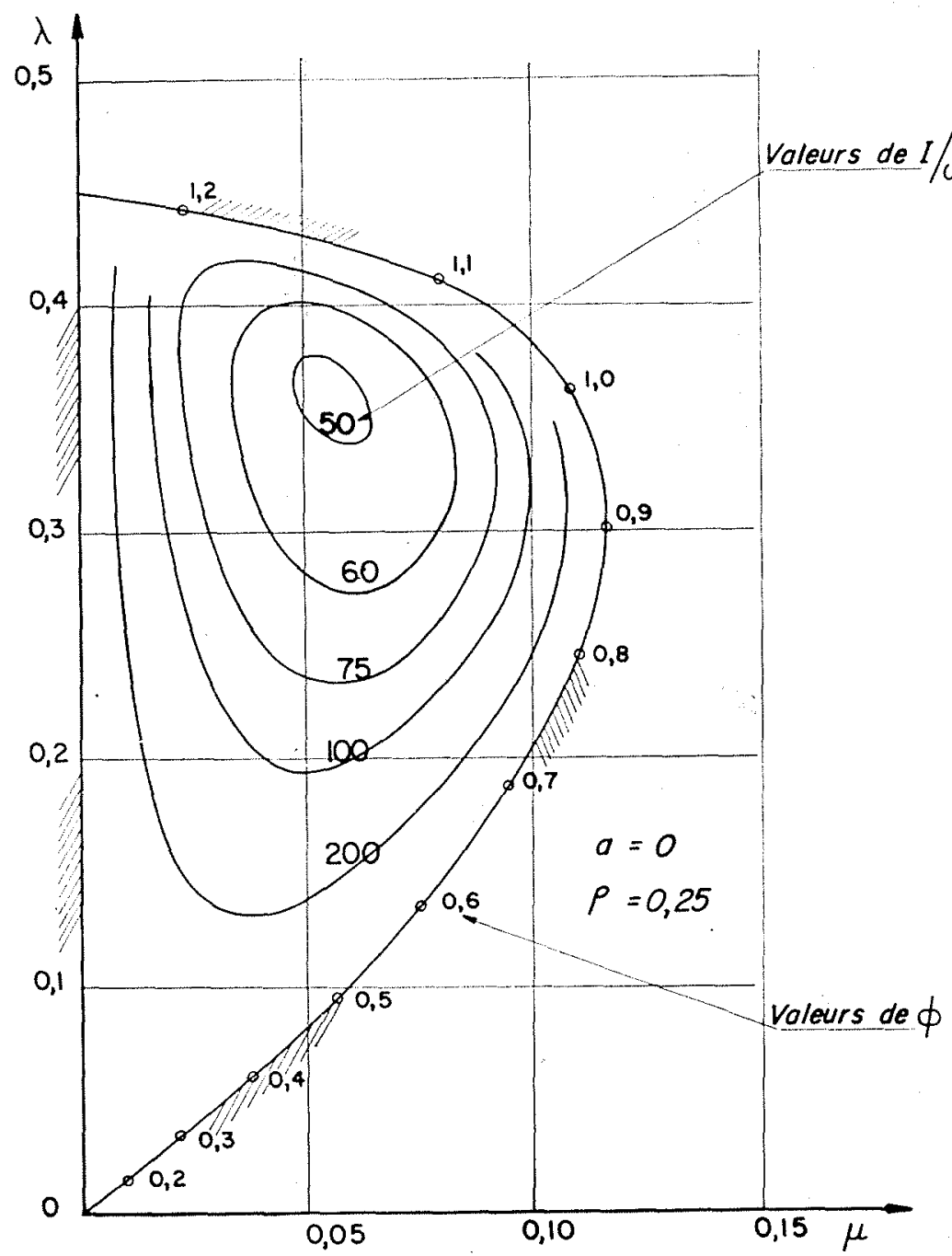

FIG. 5

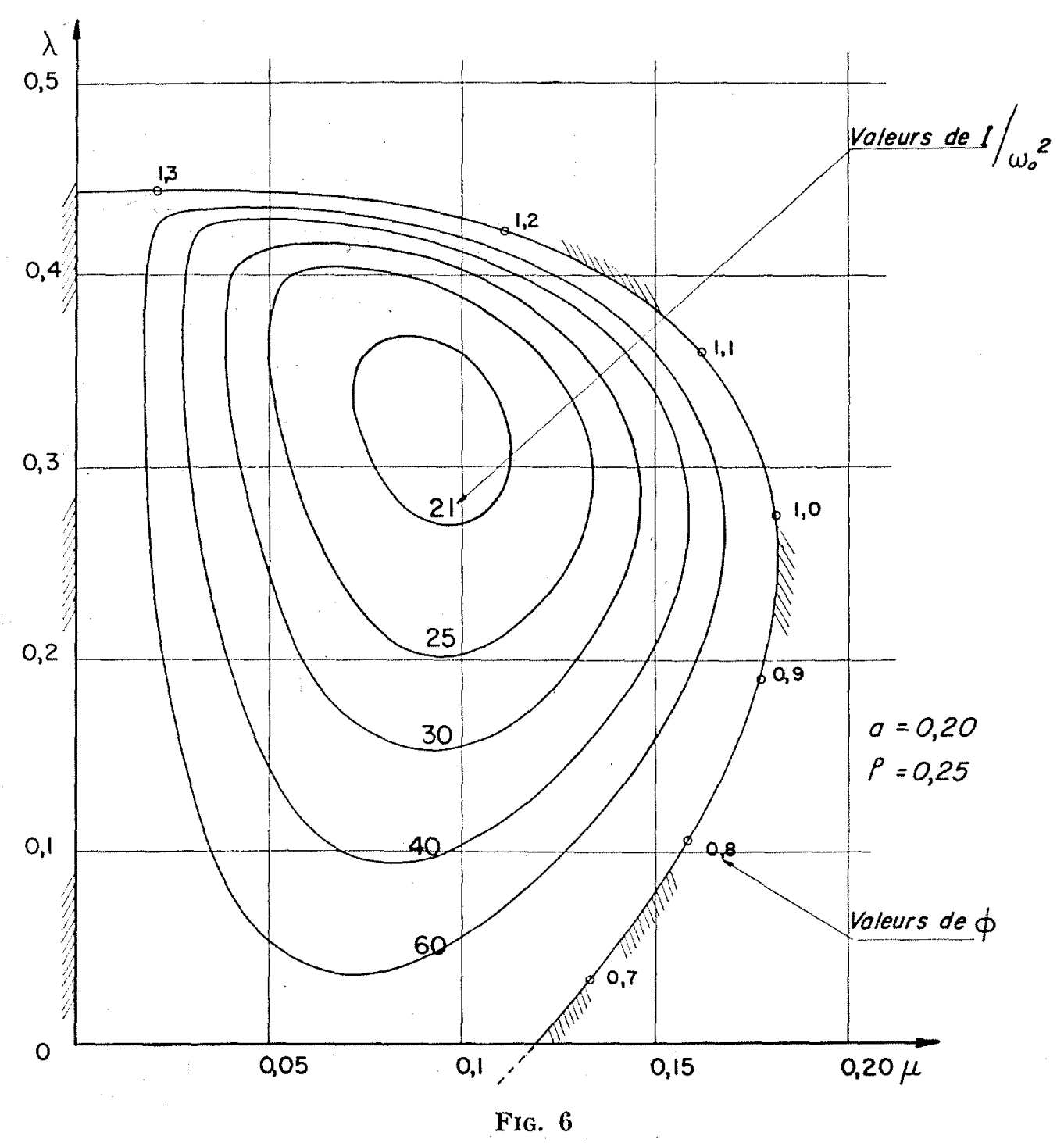




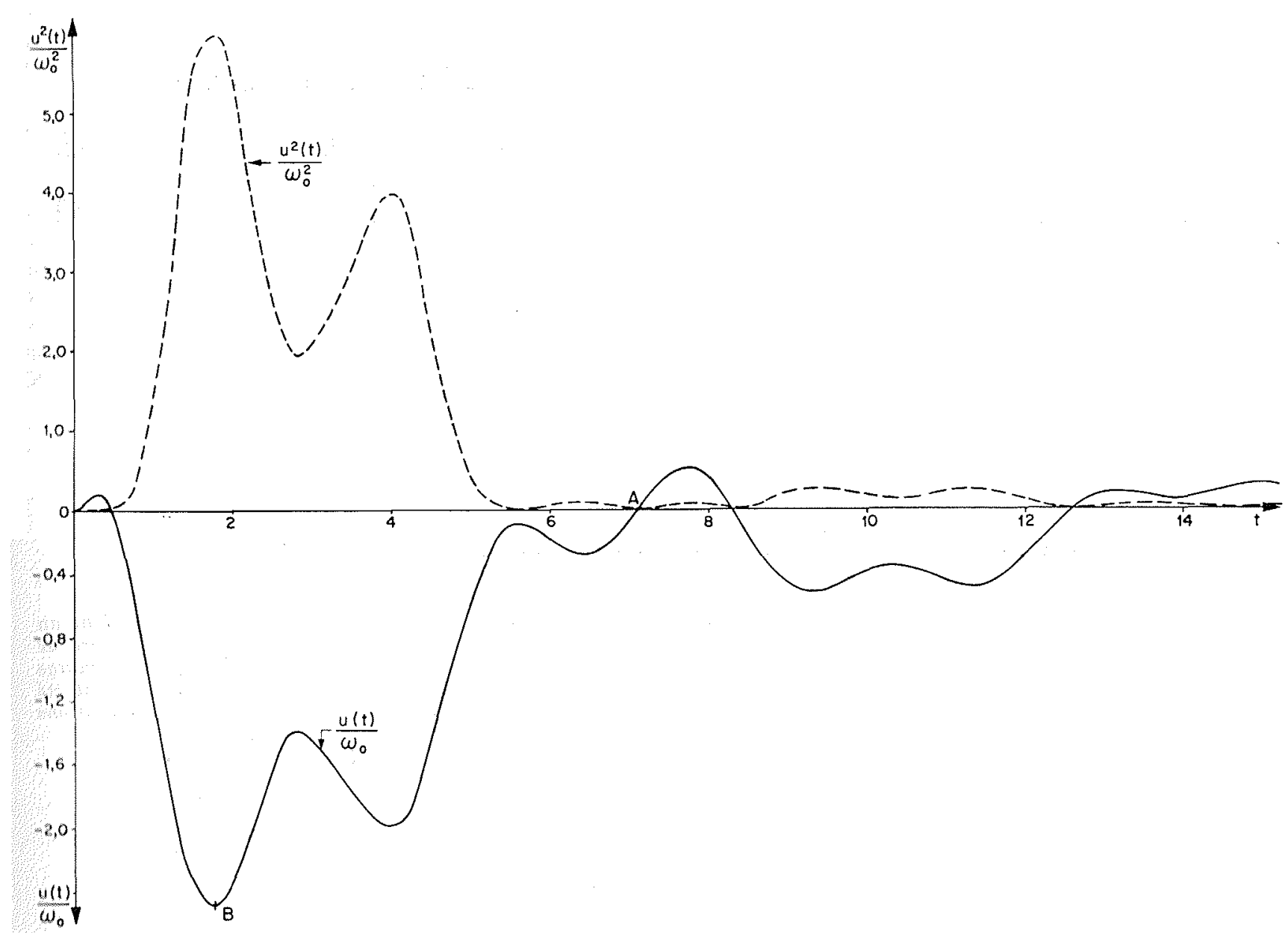

FIG. 7

\section{BIBLIOGRAPHIE}

(1) Gúnon (M.) : Influence des phénomènes de coup de bélier sur le réglage de la vitesse des turbines hydrauliques, la Houille Blanche, $\mathrm{n}^{\circ} 2,1949$.

(2) Danier (J.) : Accélération du réglage de vitesse des turbines hydrauliques, la Honille Blanche, $\mathrm{n}^{\circ \mathrm{s}} 1$ et 2,1948 .

(3) Frimbati (A. A.) : Critères intégraux de la qualité de réglage, Automatika i telemelhanika, tome IX, I1" 1,1948 .

1) Ganen (D.) : Contributions à l'étude des régulateurs de vitesse : Considérations sur le problème de la stabilité, Editions La Concorde, Lausame, 1945.

(10) Henscher (R.) : Ueber ein verallgemeinestes quadratisches Optimum, Regelungstechnik, $\mathbf{n}^{\circ} \mathbf{8}, 1956$.
(6) Kuntanann (J.), Danier. (J.) et Min-Yuan Ma : Stabilité des systèmes de réglage, Revue Générale de l'Electricite, mars et novembre 1952 (pp. 149-152, 532-538).

(7) Nasse (G.) : Etude de la stabilité de réglage de vitesse d'un groupe hydroelectrique, Bull. Soc. Francaise des Electriciens, septième série, tome 1, n' 1 , janvier 1951.

(8) Rassfond (G.) et Annaud (P.) : La détermination des earactéristiques optima d'un régleur hydraulique, compte tenu de l'autoréglage et de la pente de la courbe de rendement, la Honille Blanche, $n^{\circ} 3$, 1958. 


\title{
L'optimisation des caractéristiques d'un régleur hydraulique compte tenu de l'autoréglage et du coup de bélier d'onde
}

\author{
Cas des turbines Pelton ${ }^{*}$
}

\author{
PAR G. RANSFORD EN J. ROTWNER \\ INGÉNIEURS A LA SOCIÉTÉ GRENOBLOISE D'ÉTUDES ITT D'APPLICATHONS HYDRACLIQUES, GRENOBLE \\ English text, p. 23 \\ Cet article fait suite à celui de MM. G. Ransford et P. Arnaud (La Houille Blanche, \\ $\mathbf{n}^{\circ} 3,1958$, p. 220) consacré au cas des turbines Francis.
}

\begin{abstract}
La première partie de cet article traite du réglage de la vitesse d'une turbine Pelton. compte tenu du coup de bélier d'onde et du coefficient d'autoréglage du réseau. A l'intérieur de la zone de stabilité, les auteurs déterminent l'intégrale caractérisant au mieux la précision du réglage (d'une manière analogue à ce quit a été fait auparavant pour les Francis). Les résultats sont portés sur six graphiques.
\end{abstract}

Dans la seconde partie, les auteurs étudient un exemple numérique. En particulier, l'écart de vitesse de la machine après une prise de charge. est chiffré, les paramètres de réglage ayant été choisis an préalable d'après les considérations développées précédemment.

\section{INTRODUCTION}

Le problème difficile de la régulation des turgines Pelton, ou, en général, des turbines de haute chute, semble avoir été traité pour la première fois par M. Gaden [4] et ensuite par le R. P. Daniel dans sa thèse [2]. Parmi les auteurs qui l'ont abordé depuis, on peut citer, en langue française, M. Cuénod [1], M. Nasse [7], et MM. Kuntzmann, Daniel et Ma [6] ${ }^{* *}$.

Pour des raisons analogues à celles qui ont motivé la rédaction d'un article précédent [8] consacré à la régulation des turbines Francis de $n^{s} \cong 200$, nous avons jugé utile de reprendre cette étude. Ces raisons sont les suivantes :

§ 1 : De façon générale, la littérature existante ne prétend pas examiner simultanément tous les facteurs qui influent sur le comportement d'un groupe donné : dans le cas des turbines Pelton, on néglige le plus souvent l'autoréglage du réseau.
8 2: Faute d'outils mathémaliques adaptés à la tâche, on n'a pu aborder dans toute sa généralité la détermination du dosage optimum de chacun des éléments du régleur:

-- accéléromètre/tachymètre, ou :

- temps de relaxation du dash-pot/pente de la came de statisme temporaire, suivant le type de règleur dont il s'agit.

Ainsi que dans le cas des turbines Francis, nous retrouvons ici beaucoup de considérations empiriques sur ce qui peut constituer le meilleur réglage; ce n'est pas surprenant, car on voit mal comment, à défaut du théorème de Krasorsky [8], ou du moins d'une méthode d'analyse comparable, on pourrait aboutir à un résultat entièrement satisfaisant pour l'esprit.

On appréciera d'ailleurs. à lá suite de notre

(") Trnater, relatif à l'étude précédente, parue dans notre numéro 3 de 1958 , page 226, colonne 1, 2* ligne, équation (10), lire :

(*) Bibliographie, p. 37.

$$
I=\frac{4 \mathrm{~B}+\mathrm{D}}{2 \mathrm{D}(\mathrm{BC}-\mathrm{D})} w_{0}{ }^{2} \quad \text { au lieu de } \mathrm{I}=\frac{4 \mathrm{~B}+\mathrm{D}}{2 \mathrm{D}(\mathrm{BC}-\mathrm{D})}
$$


exposé, quels services inappréciables ce théorime est capable de fournir. L'évaluation de Pintégrale I ou d'intégrales semblables caraclerisant la précision de réglage par d'autres procédés - calcul direct, analyse de Feldbutm [3] [5] - devient en effet très difficile à envisager dans le cas présent, même si, pour l'équation linéaire de troisième ordre traitée précédemment, ces méthodes pouvaient à la rigueur être envisagées (quoique tu prix d'un travail supplémentaire énorme). Si lon considère la méthode de Feldbaum, on sait qu'au cours du calcul afférant à une équation diflérentielle, de $n^{\text {iềue }}$ ordre, on doit résoudre $n(n+1) / 2$ équations algébriques simultanées. Dans la méthode de Krasovsky, outre que tous les facteurs qui interviennent dans les calculs sont donnés sous forme explicite, on n'a qu'un système de $n$ ou $(n-1)$ équations algébriques à résoudre, pour des systèmes à statisme permanent et des systèmes astatiques (comme ici) respectivement. Lorsque, dans le cas d'un asservissement à retard fini ou soumis à des coups de bélier d'onde, on doit traiter un système infini d'équations, convergeant toutefois à l'intérieur' de la zone de stabilité, on conçoit que seule l'analyse de Krasovsky puisse convenir.

\section{NOTATIONS}

Les notations sont celles de l'article précédent [8], avec, en plus, les suivantes :

$$
\begin{array}{cl}
k_{1} k_{2} k_{3} k_{t} & : \text { constantes d'intégration. } \\
p & : \text { nombre complexe figurant dans la transformation de Laplace. } \\
x & =\mathrm{X} / \mathrm{L} .
\end{array}
$$

$x_{1} x_{2} x_{3} \ldots x_{n-1}$ : solutions du système classique de $(n-1)$ équations simultanées de Krasovsky : ici $n=6$ ou 8 .

J $\quad$ : le temps mis par l'onde de compression (ou dépression) pour parcourir la distance $L$ séparant la turbine de la prise.

$\mathrm{V}=\mathrm{V}_{n}+\Delta \mathrm{V}$.

$\mathrm{V}_{n} \quad$ : vitesse dans la conduite forcée à l'ouverture $n$.

$\mathrm{X} \quad$ : distance comptée le long de la conduite forcée depuis la turbine.

on : produit de la vitesse de propagation de l'onde dans la conduite et de $\left(\mathrm{Q}_{n} / 2 g \mathrm{HS}\right)=\left(\mathrm{V}_{n} / 2 g \mathrm{H}\right)$. On écrira $p$ simplement lorsqu'aucune confusion ne pourra en résulter.

$\varphi \quad=p / 2 q_{n} i$.

Il sera toutefois utile de rappeler la signification de certains paramètres déjà employés :

$$
\begin{aligned}
& a=\frac{c_{n} f_{n}^{2}{ }^{20}}{\tau} \text { A le coefficient d'autoréglage en variables réduites. } \\
& c_{n}=\frac{\eta_{1}}{r_{1 n}} \quad: \text { l'inverse du rendement relatif. } \\
& f_{n}=\frac{\mathrm{Y}_{n}}{c_{n}} \quad: \text { la puissance relative. } \\
& t=\frac{\mathrm{T}}{c f_{0}} \quad: \text { le temps en variables réduites ( } \mathrm{T}=\text { temps en secondes). } \\
& u=\frac{\tau}{c f^{2 \theta}} \frac{\Delta \Omega}{\Omega_{1}}: \text { l'écart de vitesse de la roue en variables réduites. } \\
& w_{0}=\frac{\Delta \mathrm{W}}{\mathrm{W}_{n}}: \text { la variation relative de la puissance demandée. } \\
& \mathrm{I} \quad=\int_{0}^{\infty} u^{2} d t .
\end{aligned}
$$

$\mathrm{K}_{\mu} \mathrm{K}_{\lambda} \quad$ : constantes du régleur (rapidités de réponse de l'élćment tachymétrique et de l'élément accélérométrique, respectivement). 


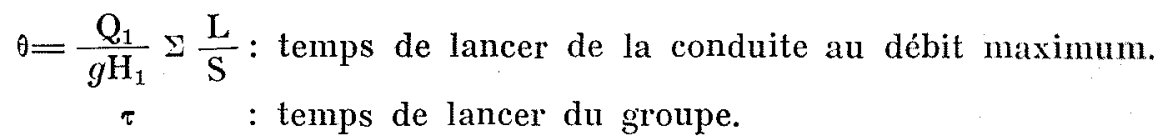

On a employé des caractères gras pour les transformées de Laplace. Les variables $h_{a} q_{v}$ désignent les valeur's des écarts de pression et de débit au point $x$. Pour $x=0$, (au droit de la turbine), on a, par définition $h_{x=0}=h$ et $q_{x=0}=q$.

\section{EQUATIONS REGISSANT LA ROTATION D'UN GROUPE HYDROELECTRIQUE}

Nous rappelons brièvement les équations que nous avons établies précédemment en variables réduites [8] :

- Equation de rotation de la roue :

$$
\frac{d u}{d t}=q+h-w_{0}-a u
$$

- Equation donnant le débit de la turbine :

$$
q=y+\frac{1}{2} h
$$

- Equation du régulateur :

$$
\frac{d y}{d t}=-u \cdot u-\lambda \frac{d u}{d t}
$$

Notons que :

- Dans (1), nous négligeons la variation de rendement, insignifiante pour les Pelton.

- Dans (2), nous avons supposé une loi d'orifice qui s'applique en toute rigueur, bien entendu, aux Pelton.

- Dans (3), nous avons admis la mème loi que pour le régulateur d'une Francis; autrement dit, nous n'avons pas tenu compte de l'intervention éventuelle du déflecteur pendant les grandes manœuvres de réglage. L'équation est valable pour les fines variations de réglage seulement (à noter que le déflecteur se tient normalement à une certaine distance du jet).
Il convient d'écrire ces trois expressions en transformées de Laplace. Il s'agit, comme on le sait, de multiplier par $e^{p t}$ et ensuite d'intégrer de 0 à $\infty$ par rapport à $t$.

Il vient :

$$
\begin{gathered}
p \mathbf{u}=\mathrm{q}+\mathrm{h}-\left(w_{0} / p\right)-a \mathbf{u} \\
\mathrm{q}=\mathrm{y}+(1 / 2) \mathbf{h} \\
p \mathrm{y}=-\dot{u}-\lambda p \mathbf{u}
\end{gathered}
$$

A noter que le terme - $w_{0} / p$ traduit l'influence d'une prise de charge brutale relative $w_{0}$ à l'ins$\operatorname{tant} t=0$.

L'élimination de $\mathbf{u}$ et de $\mathbf{y}$ donne l'équation qui suit :

$\left\{p^{2}-(2 \lambda-a) p-2 \mu\right\} \mathbf{h}=2\left\{p^{2}+(a+\lambda) p+\mu\right\} \mathbf{q}$

$$
-\frac{2 w w_{0}(u+\lambda p)}{p}
$$

Cette expression va nous être utile dans la détermination des conditions de stabilité. Par contre, pour examiner le comportement du système réglé à l'intérieur de la zone de stabilité par la méthode de Krasovsky, nous aurons besoin d'une expression en $u$ obtenue par l'élimination de $q, y$ et $h$; nous y reviendrons après avoir mis en équation le coup de bélier d'onde.

\section{EQUATION DU COUP DE BELIER D'ONDE}

Nous rappelons très brièvement l'analyse classique qu'on trouvera sous une forme plus détaillée dans les ouvrages cités en référence :

Les équations de base :

$$
\frac{\partial \mathrm{V}_{w}}{\partial \mathrm{T}}=g \frac{\partial \mathrm{H}_{x}}{\partial \mathrm{X}} ; \quad \frac{\partial \mathrm{V}_{x}}{\partial \mathrm{X}}=\frac{g}{a^{2}} \frac{\partial \mathrm{H}_{w}}{\partial \mathrm{T}}
$$

peuvent s'écrire en variables réduites sous la forme :

$\frac{\partial q_{x}}{\partial t}=\frac{c f \theta}{2 \rho_{n} J} \frac{\partial h_{r}}{\partial x} ; \quad \frac{\partial q_{x}}{\partial x}=\frac{1}{2 \rho_{n} J c f \theta} \frac{\partial h_{i x}}{\partial t}$

étant donné que :

$$
\mathrm{V}=(1+q) \mathrm{V}_{n}
$$


On se rappelle que :

$$
t=\frac{\mathrm{T}}{c f 0}
$$

to temps en variables sans dimensions, et que :

$$
c f 0=\frac{\mathrm{Q}_{n}}{g \mathrm{H}_{1}} \mathrm{\Sigma} \frac{\mathrm{L}}{\mathrm{S}}
$$

le temps de lancer de la conduite rapporté au débit $\mathrm{Q}_{n}$ considéré.

Les équations (9) fournissent les expressions suivantes :

$\frac{\partial^{2} q_{x}}{\partial x^{2}}=\left(\frac{\mathrm{J}}{c f^{0}}\right)^{2} \frac{\partial^{2} q_{x}}{\partial t^{2}} ; \quad \frac{\partial^{2} h_{x}}{\partial x^{2}}=\left(\frac{\mathbf{J}}{c f^{0}}\right)^{2} \frac{\partial^{2} h}{\partial t^{2}}$

oll :

$\frac{\partial^{2} q_{x}}{\partial x^{2}}=\frac{1}{4 \rho_{n}^{2}} \frac{\partial^{2} q_{x}}{\partial t^{2}} ; \quad \frac{\partial^{2} h_{x}}{\partial x^{2}}=\frac{1}{4 \varphi_{n}^{2}{ }^{2}} \frac{\partial^{2} h_{x}}{\partial t^{2}}(10)$

car, par définition :

$$
\frac{\mathrm{J}}{c f \theta}=\frac{1}{2 q_{n}}
$$

Appliquons la transformation de Laplace à (10); il vient :

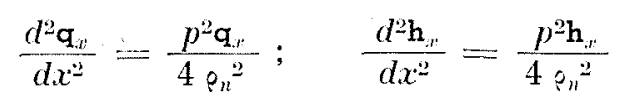

équations dont les solutions sont respectivement (compte tenu des conditions initiales, à l'instant où nous admettons qu'il se produit un saut brusque de puissance survenant en régime permanent) :

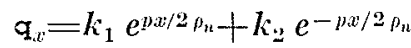

$$
\begin{aligned}
& \mathbf{h}_{u}=k_{3} e^{p, r / 2 \rho_{n}}+k_{4} e^{-\mu x / 2 \rho_{n}}
\end{aligned}
$$

On sait d'après (9) que :

$$
k_{3}=2_{\wp_{n}} k_{1} ; \quad k_{4}=-2_{\wp_{n}} k_{2}
$$

D'autre part, à l'extrémité amont de la conduite, la surpression est nulle :

$$
h_{x=1}=0
$$

De même, au droit de la turbine, nous savons par définition que :

$$
\begin{aligned}
& h_{x=0}=h \\
& q_{x=0}=q
\end{aligned}
$$

Finalement, on trouve pour $h$ et $q$ les expressions que voici :

$$
\begin{aligned}
& \mathrm{h}=2 \varrho_{n} k_{1}\left\{1-e^{n / p_{n}}\right\} \\
& \mathrm{q}=k_{1}\left\{1+e^{p / p_{n}}\right\}
\end{aligned}
$$

c'est-à-dire :

$$
\mathrm{h}=-2 \rho_{n} \mathrm{q} \operatorname{tgh}\left(p / 2 \varsigma_{n}\right)
$$

\section{DÉTERMINATION DE LA ZONE DE STABILITE}

Il vient, après élimination de h entre les équations (7) et (11) :

$$
\left[\left\{p^{2}+(a+\lambda) p+\mu\right\}+\varphi_{n}\left\{p^{2}-(2 \lambda-a) p-2 \mu\right\} \operatorname{tgh}\left(p / 2 \rho_{n}\right)\right] \mathrm{q}=-\left(w_{0} / p\right)[\mu+\lambda p]
$$

On sait que les limites de stabilité sont déterminées par le coefficient de q.

Ce problème a été étudié auparavant; nous n'en aborderons pas l'analyse détaillée. Il suffit en pratique, pour retrouver la courbe qui définit la zone de stabilité du côté de $\mu$ croissant, de remplacer $p$ par $2 \rho_{n} i$, ainsi que nous allons le faire, dans le coefficient en question mis égal à zéro.

Ecrivant, pour plus de simplicité, : pour en, nous trouvons l'équation suivante:

$$
\begin{array}{r}
2 \rho\left\{\frac{\varphi^{2}}{2}+\frac{\mu}{4 \varphi^{2}}+\left(\lambda-\frac{a}{2}\right) \frac{i \varphi}{2 \rho}\right\} \operatorname{tg} \varphi=(\lambda+a) \frac{\varphi}{2 \rho} \\
+i\left(\varphi^{2}-\frac{\mu}{4 \varphi^{2}}\right)
\end{array}
$$

d'où on tire les égalités :

$$
\begin{aligned}
& 2 \varphi\left\{\frac{\varphi^{2}}{2}+\frac{\mu}{4 \varphi^{2}}\right\} \operatorname{tg} \varphi=(\lambda+a) \frac{\varphi}{2 \varphi} \\
& \left(\lambda-\frac{a}{2}\right) \varphi \operatorname{tg} \varphi=\left(\varphi^{2}-\frac{\mu}{4 \rho^{2}}\right)
\end{aligned}
$$

Il en résulte les formules définitives, domnées en termes du paramètre $\%$ :

$$
\begin{gathered}
y=4 \vartheta^{2} \varphi^{2}\left\{\frac{1-2 \rho^{2} \operatorname{tg}^{2} \varphi}{1+4 \rho^{2} \operatorname{tg}^{2} \varphi}\right\}+a \frac{6 \rho^{2} \varphi \operatorname{tg} \varphi}{\left(1+4 \rho^{2} \operatorname{tg}^{2} \varphi\right)} \\
\lambda=\frac{6 \rho^{2} \circ \operatorname{tg} \rho}{1+4 \rho^{2} \operatorname{tg}^{2} \varphi}-a\left\{\frac{1-2 \rho^{2} \operatorname{tg}^{2} \varphi}{1+4 \rho^{2} \operatorname{tg}^{2} \varphi}\right\}(14)
\end{gathered}
$$


Le R.P. Daniel [2] a déjà, dans sa thèse, donné des expressions semblables mais pour le cas $a=0$. Pour une discussion plus complete on se reportera à cette publication.

L'autre frontière de la zone de stabilité est l'axe des $\lambda$ :

$$
\mu=0
$$

On remarquera que la période des oscillations entretenues définies par $ڤ$ est de :

$$
\frac{2 \pi c f 0}{0_{n} 0}=\frac{\pi}{2} \times 4 \mathrm{~J} \text { secondes }
$$

Or, $4 \mathrm{~J}$ est la période propre de la conduite. On vérifie que :

$$
\frac{\pi}{2 \varphi}>1 \text { oll } \varphi<1,57
$$

dans tous les cas, ainsi que cela a été souligné par le R. P. Daniel [2].

\section{APPRECIATION DE LA PRECISION DE REGLAGE D'UN SYSTEME ASSERVI VIS-A-VIS D'UNE PERTURBATION BRUTALE}

Nous ne reviendrons pas ici en détail sur ce qui a été dit dans l'article précédent [8]. Il suffit de rappeler qu'il y a de bonnes raisons pour préférer à tout autre critère de la finesse de réglage, l'intégrale :

$$
\mathrm{I}=\int_{n}^{\infty} u^{2} d t
$$

soit, l'intégrale de l'écart relatif carré de la vi- tesse du groupe à la suite d'un brusque saut de puissance. En fait, vu que l'écart de vitesse est proportionnel à $w_{0}$, la variation relative de puissance, on étudie plus précisément les valeurs de $\left.\mathrm{I} / w_{0}\right)^{2}$.

Le dosage optimum des caractéristiques du régleur correspond, en gros, à la valeur minimum de $\mathrm{I} / w_{0}{ }^{2}$.

\section{APPLICATION DU THEOREME DE KRASOVSKY}

L'utilisation du théorème exige d'abord qu'on écrive une équation pour $u$ en termes de $w_{0}$, les variables $\mathrm{q}, \mathrm{y}$ et $\mathrm{h}$ étant éliminées.

On trouve ainsi l'équation suivante:

$$
\left\{\left[p^{2}+(a+\lambda) p+\mu\right]+\left[p^{2}-(2 \lambda-a) p-2 \mu\right] \rho \operatorname{tgh}(p / 2 \rho)\right\} \mathbf{u}=-w_{0}\{1+\rho \operatorname{tgh}(p / 2 \rho)\}
$$

Comme il fallait s'y attendre, le multiplicande de u s'identifie à celui figurant dans l'équation (12) pour q; en effet, comme il a déjà été expliqué, ce coefficient détermine les limites de stabilité du système dans son ensemble.

Le développement en série de la tangente hyperbolique ne convient pas ici, en raison àu problème de convergence pour de faibles valeurs de $p$. On multiplie donc par cosh $(p / 2$ p), ce qui donne :

$$
\begin{aligned}
& \left\{\left[p^{2}+(a+\lambda) p+p\right] \cosh (p / 2 p)+\left[p^{2}-(2 \lambda-a) p-2 \beta\right] p \sinh (p / 2 q)\right\} u \\
& =-w_{0}\{\cosh (p / 2 p)+p \sinh (p / 2 p)\}
\end{aligned}
$$


Le développement en série fournit une succossion de termes dont voici ceux figurant dans lo multiplicande de $u$ :

Constante : $p$

$$
\begin{aligned}
& p: a+\lambda-\mu \\
& p^{2}: 1+\frac{\mu}{8 q^{2}}-\lambda+\frac{a}{2} \\
& p^{3}: \frac{a+i}{8 q^{2}}+\frac{1}{2}-\frac{\mu}{24 \rho^{2}} \\
& p^{4}: \frac{1}{8 q^{2}}+\frac{y}{384 q^{4}}-\frac{[\lambda-(a / 2)]}{24 q^{2}} \\
& p^{5}: \frac{a+\lambda}{384 \rho^{-1}}+\frac{1}{48 q^{2}}-\frac{\mu}{1920 q^{1}} \\
& p^{6}: \frac{1}{384 q^{4}} \quad+\frac{\mu}{46080 \rho^{63}}-\frac{[\lambda-(a / 2)\rceil}{1920 \rho^{4}} \\
& p^{i}: \frac{a+\lambda}{46080 \rho^{6}}+\frac{1}{38400^{4}} \\
& p^{8}: \frac{1}{46080 ?^{6}}
\end{aligned}
$$

ol ainsi de suite. En fait, nous avons considéré cleux approximations :

L'une où nous avons négligé les termes dans les développements en série au-delà de la puissance $(p / 2 o)^{4}$; on s'arrête alors à la première ligne brisée dans le tableau ci-dessus, c'est une approximation correspondant à une équation différentielle d'ordre 6 .

-- L'autre comportant des termes dans l'expansion du sinus et du cosinus hyperboliques jusqu'à $(p / 2)^{6}$ inclus; tous les coefficients explicités dans le tableau précédent sont à conserver. Nous assimilons ainsi notre problème à la résolution d'une équation différentielle linéaire d'ordre 8 .

Le mème procédé appliqué au multiplicande de $-w_{0}$ aboutit au résultal suivant :

$$
\begin{aligned}
\text { Constante } & : 1 \\
p & : \frac{1}{2} \\
p^{2} & : \frac{1}{\delta q^{2}} \\
p^{3} & : \frac{1}{48 q^{2}} \\
p^{4} & : \frac{1}{384 q^{4}} \\
p^{5} & : \frac{1}{3840 q^{4}} \\
p^{6}: & \frac{1}{46080 ?^{6}}
\end{aligned}
$$

et ainsi de suite.

Le théorème de Krasovsky donne alors le résultat que voici :

$$
\frac{\mathrm{I}}{w_{0}^{2}} \approx \frac{1}{2 \mu}\left\{x_{1}+\frac{\rho^{2}-1}{4 \rho^{2}} x_{2}+-\frac{1}{\left[46080 \rho^{13}\right]^{2}} x_{7}\right\}
$$

lans le cas de l'approximation d'ordre 8.

Le calcul pour l'approximation d'ordre 6 est encore plus simple :

$$
\frac{\mathrm{I}}{w_{0}{ }^{2}} \cong \frac{1}{2 \mu}\left\{x_{1}^{\prime}+\frac{\rho^{2}-1}{4 \rho^{2}} x_{2}^{\prime}+--+\frac{1}{\left(384 \rho^{4}\right)^{2}} x_{5}^{\prime}\right\}
$$

ou les $x_{1}^{\prime} x_{2}^{\prime}-x_{5}^{\prime}$ s'identifient à peu de chose près aux $x_{1} x_{2}-x_{5}$ de la formule jrecédente; le système des équations simultanées qui les déterminent n'est plus toutefois que lordre 5 au lieu d'ordre 7.

\section{CALCULS SUR MACHINE I.B.M. A CARTES PERFOREES}

Nous avons effectué des calculs complets en prenant l'approximation d'ordre 6 pour les cas tuivants (temps de calcul par point $=17$ serondes) :

$$
\begin{array}{ll}
a=0 & \wp=1 \\
a=0,2 & \wp=1 \\
a=0 & \wp=0,5
\end{array}
$$




$$
\begin{array}{ll}
a=0,2 & q=0,5 \\
a=0 & q=0,25 \\
a=0,2 & ?=0,25
\end{array}
$$

Les résultats sont présentés sur les graphiques accompagnant le texte $\left(^{\star}\right)$. Notons que les cas limites :

$$
\begin{array}{ll}
a=0 & \wp=\infty \\
a=0,2 & \wp=\infty
\end{array}
$$

ont déjà été étudiés dans l'article précédent [8] sous les rubriques :

$$
\begin{array}{ll}
a=0 & b=0 \\
a=0,2 & b=0
\end{array}
$$

respectivement.

L'emploi de l'approximation d'ordre 6 s'est avéré tout à fait suffisant même pour $p=0,25$, ainsi que quelques comparaisons avec celle d'ordre 8 l’ont démontré. Ainsi nous avons trouvé les valeurs comparées que voici dans quatre cas-types :

1") $a=0 ; \quad q=1 ; \quad \lambda=0,6 ; \quad \mu=0,1$

- Approximation d'ordre 6, c'est-à-dire en ne conservant, dans les développements en série, que les termes jusqu’à $\left(p / 2{ }^{\prime}\right)^{4}$ :

$$
\mathrm{I}=15,355 \mathrm{zv}^{2}
$$

- Approximation d'ordre 8, c'est-à-dire avec les termes juscu'à $(p / 20)^{6}$ :

$$
\mathrm{I}=15,362 w_{0}^{2}
$$

$\left.2^{\circ}\right) \quad a=0,2 ; \quad \circ=1 ; \quad \lambda=0,3 ; \quad \mu=0,1$

- Approximation d'ordre $6: I=15,450 w_{0}{ }^{2}$

- Approximation d'ordre $8: I=15,451 w_{0}{ }^{2}$

$\left.3^{\circ}\right) \quad a=0 ; \quad=0,25 ; \quad \lambda=0,3 ; \quad \mu=0,05$

- Approximation d'ordre $6: \mathrm{I}=55,905 \mathrm{w}_{0}^{2}$

- Approximation d'ordre $8: \mathrm{I}=56,150 \mathrm{w}_{0}{ }^{2}$

$\left.4^{\circ}\right) \quad a=0,2 ; \quad ?=0,25 ; \quad \lambda=0,3 ; \quad \mu=0,05$

- Approximation d'ordre $6: \mathrm{I}=38,468 \mathrm{w}_{0}{ }^{2}$

- Approximation d'ordre $8: \mathrm{I}=38,492 w_{0}{ }^{2}$

\section{Discussion des résultats :}

Sur les six graphiques donnant les valeurs de $\mathrm{I} / w_{0}{ }^{2}$ nous avons également porté les valeurs de ○ autour de la périphérie de la zone de stabilité.

(“) Ces graphiques se trouvent à la fin du texte anblais, p. 32 à 37 .
Rappelons que la période des oscillations entretenues caractérisant l'instabilité est de :

$$
\frac{2 \pi \% 0}{0 \%}
$$

L'influence de l'autoréglage est considérable; ainsi que dans le cas des turbines Francis, on aurait tort de le négliger. Ici aussi, on aura intérêt à se placer un peu à gauche et en bas du « cour » de la colline. Pour le cas $a=0 ; 0:=1$, par exemple, la valeur minimum de I se situe à :

$$
\begin{aligned}
& \mu=0,11 \\
& \lambda=0,65
\end{aligned}
$$

Il serait indiqué de prendre en réalité des valeurs telles que :

$$
\begin{aligned}
& \eta=0,10 \\
& \lambda=0,62
\end{aligned}
$$

\section{Exemple numérique :}

Une turbine Pelton (2 roties, 2 jets), d'une puissance nominale de $13500 \mathrm{ch}$, est alimentée sous une chute de $347 \mathrm{~m}$. Le débit à pleine ouverture étant de $3,27 \mathrm{~m}^{3} / \mathrm{s}$, et la valeur de $\mathrm{xLV}$ de 2480 , on trouve que le temps de lancer $\theta$ de la conduite est de 0,73 secondes.

D'autre part, l'inertie du rotor est de 70 t.m². La vitesse de rotation étant de $500 \mathrm{tr} / \mathrm{mm}$, on obtient pour le temps de lancer du groupe $\tau$ la valeur :

$$
r=\frac{70 \times(500)^{2}}{270 \times 13500}=4,8 \text { secondes }
$$

La vitesse de propagation des ondes élastiques est prise égale à $1000 \mathrm{~m} / \mathrm{s}$. L'écoulement dans la conduite forcée à l'ouverture maximum se faisant à une vitesse de $3,92 \mathrm{~m} / \mathrm{s}$, il vient :

$$
Q_{1}=0,576
$$

Le groupe dont il s'agit alimente un réseau séparé. On veut savoir quelle variation de vitesse résultera lorsque, pour une marche à une puissance relative de $80 \%$, il survient un brusque appel de puissance. On peut supposer que le régleur est conçu de manière à pouvoir réaliser pour chaque ouverture (donc chaque valeur de on) la combinaison optimum des éléments (tachymétrique/accélérométrique) on (pente de la came de statisme/rigidité du dash-pot). On suppose que le coefficient d'autoréglage du réseau, $A$, vaut 1,5 ; c'est un chiffre courant.

Le rendement varie très peu avec l'ouverture, bien entendu; cependant, il se trouve que le ren- 
tement à $80 \%$ dépasse celui à la puissance maximum de $0,5 \%$.

II vient alors :

$$
c_{0,80}=0,995 \quad f_{0,80}=0,80 \quad a=\frac{0,995 \times(0,80)^{2} \times 0,73}{4,8} 1,5=0,145 \quad 9_{0.80}=0,458
$$
wnibles:

Par ailleurs, après interpolation dans nos graphiques, on peut choisir comme valeurs con-

$$
\begin{aligned}
& \mu=0,11 \\
& \lambda=0,50
\end{aligned}
$$

wi qui donne :

$$
\mathrm{K}_{\mu}=\frac{4,8}{0,995 \times(0,80)^{2} \times(0,73)^{2}} 0,11=1,56 \text { secondes }^{-1} \quad K_{\lambda}=\frac{4,8}{0,80 \times 0,73} \quad 0,50=4,1
$$

Dans un régleur à statisme temporaire ces valeurs correspondraient à une pente de la came Ite statisme de:

"il a un temps de relaxation du dash-pot de :

$$
\frac{1}{\mathrm{~K}_{\lambda}}=\frac{1}{4,1}
$$

$$
\frac{\mathrm{K}_{\lambda}}{\mathrm{K}_{\mu}}=\frac{4,1}{1,56}=2,64 \text { secondes }
$$

L'équation différentielle (approximation d'ordre 6), régissant la variation de la vitesse de la woue en fonction du temps s'écrit, après avoir subi la transformation de Laplace :

u $\left[\frac{1}{384 \rho_{n}{ }^{4}} p^{6}+\left\{\frac{a+\lambda}{384 \rho_{n}{ }^{4}}+\frac{1}{48 \rho_{n}{ }^{2}}\right\} p^{5}+\left\{\frac{1}{8 \rho_{n}{ }^{2}}+\frac{\mu \cdot}{384 \varphi_{n}{ }^{2}}-\frac{[\lambda-(a / 2)]}{24 \rho_{n}{ }^{2}}\right\} p^{4}\right.$

$$
\begin{aligned}
& \left.+\left\{\frac{a+\lambda}{8 \rho_{n}^{2}}+\frac{1}{2}-\frac{\mu}{24 \rho_{n}^{2}}\right\} p^{3}+\left\{1+\frac{\mu}{8 \rho^{2}}-\lambda+\frac{a}{2}\right\} p^{2}+\{a+\lambda-\mu\} p+\mu\right]=
\end{aligned}
$$

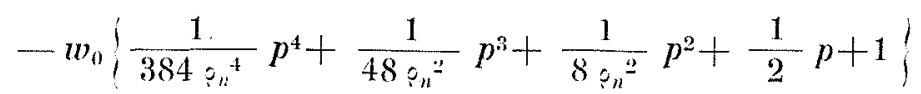

Elle devient, après remplacement des divers paramètres par leurs valeurs numériques :

11 $\left.p^{3}+2,3231 p^{5}+8,7439 p^{4}+14,5733 p^{3}+10,7807 p^{2}+9,0396 p+1,8586\right]$

$$
=-w_{0}\left(p^{4}+1,6781 p^{3}+10,069 p^{2}+8,4482 p+16,896\right)
$$

Nous chercherons les racines du polynôme, membre de gauche, par la méthode de Dandelincuncfe. On sait qu'elle consiste à former successivement les équations ayant pour racines les puissances seconde, quatrième, huitième, etc... des racines de l'équation initiale. Les écarts en modules entre los racines deviennent assez importants pour que l'on puisse négliger les petites racines en face des furundes. Il s'est trouvé suffisant de former l'équation aux puissances $32^{\text {èmes. }}$

Soit $\mathrm{X}=p^{32}$ la puissance $32^{\text {ime }}$ d'une racine du membre de gauche :

$\mathrm{X}^{4}+1343,31 \cdot 10^{10} \cdot \mathrm{X}^{5}+9045 \cdot 10^{22} \mathrm{X}^{4}-1263,22 \cdot 10^{28} \cdot \mathrm{X}^{3}$

$$
-9658,27.10^{25} \mathrm{X}^{2}-1466,51.10^{24} \mathrm{X}+4108,97 \cdot 10^{5}=0
$$

llons de:

Cette équation a deux racines réelles et deux couples de racines imaginaires conjuguées, solu-

$$
\begin{gathered}
\mathrm{X}^{2}+1343,31.10^{10} \mathrm{X}+9045.10^{22}=0 \\
9045.10^{22} \mathrm{X}-1263,22.10^{28}=0 \\
1263,22.10^{28} \mathrm{X}^{2}+9658,27.10^{25} \mathrm{X}+1466,51.10^{24}=0 \\
-1466,51.10^{24} \mathrm{X}+4108,97.10^{5}=0
\end{gathered}
$$

On en déduit immédiatement les racines réelles :

$$
\text { Noù : } \quad \begin{array}{ll}
\mathrm{X}=139659 & \mathrm{X}=2,801871^{-19} \\
p=-1,448 & p=-0,26316
\end{array}
$$

Le calcul des racines imaginaires conjuguées a été effectué à partir des relations : 
- Somme des racines de l'équation initiale $=-2,32311$.

- Somme des inverses des racines de l'équation initiale $=\ldots .-9,03955 / 1,8586$.

- Carré du module du premier couple $=\sqrt[32]{9.045 \cdot 10^{22}}$.

- Carré du module du deuxième couple $=\sqrt[3:]{1466,51 \cdot 10^{24} / 1263,22.10^{28}}$.

On trouve, tous calculs faits :

$$
\begin{aligned}
& p=-0,18724 \pm 2,5374 i \\
& p=-0,11874 \pm 0,8598 i
\end{aligned}
$$

Nous devons, afin de pouvoir trouver la fonction $u(t)$, décomposer la fraction rationnelle qui donne $\mathbf{u}(p)$ en éléments simples :

$$
\mathrm{u}=\frac{\mathrm{A}}{p+1,448}+\frac{\mathrm{B}}{p+0,26316}+\frac{\mathrm{C} \pm \mathrm{D} i}{p+0,18724 \pm 2,5374 i}+\frac{\mathrm{E} \pm \mathrm{F} i}{p+0,11874 \pm 0,8598 i}
$$

Le calcul de A, B, C, D, E et F est assez laborieux; nous n'en donnons que le résultat :

$$
\mathbf{u}=w_{0}\left[\frac{1,052}{p+1,448}-\frac{2,644}{p+0,26316}+\frac{0,2337 \pm 0,45026 i}{p+0,18724 \pm 2,5374 i}+\frac{0,5623 \pm 0,13749 i}{p+0,11874 \pm 0,8598 i}\right]
$$

Passons de a ì $u$ :

$$
\begin{aligned}
u / w w_{0}=1,052 e^{-1,448 t}-2,644 e^{-0,26316 t}+1,0146 e^{-0,18 \tau 24 t} \sin \left(145 t^{\circ}+27,4^{\circ}\right) \\
+1,1577 e^{-0,118 \tau^{*}+t} \cos \left(49,25 t^{\prime \prime}+13,7^{\circ}\right)
\end{aligned}
$$

La figure 1 montre la variation de $u / w_{0}$ en fonction du temps. Nous avons également représenté la courbe de $u^{2}(t) / w_{0}{ }^{2}$.

Une intégration graphique rapide nous a donné :

$$
\mathrm{I}=\int_{0}^{\infty} u u^{2} d t=13,97 w_{0}^{2}
$$

alors que le théorème de Krasovsky conduit à :

$$
\mathrm{I}=13,73 \mathrm{w}_{0}^{2}
$$

C'est une vérification excellente de nos calculs.

L'oscillation la plus longue a comme période, ainsi que l'on peut s'en rendre compte à la vue de l'équation donnant $u(t), 7,3$. C'est à peu de chose près l'abscisse du point A où $u(t)$ s'annule pour la première fois.

L'excursion maximum de $u(t)$, réalisée au point $\mathrm{B}$, est :

$$
u_{m}=2,46 w_{0}
$$

soit, dans le cas qui nous intéresse :

$$
\begin{aligned}
\Delta \Omega & \left.=\frac{0,995 \times(0,80)^{2} \times 0,73}{4,5}\right\} 2,46 w_{0} \Omega_{1} \\
& =0,238 w_{0} \Omega_{1}
\end{aligned}
$$

Ainsi, une augmentation de $5 \%$ de la puissance demandée (celle-ci passant de $80 \%$ à $84 \%$ de la puissance à pleine ouverture) se traduira par un écart de fréquence maximum de 0,6 hertz, sur un réseau alimenté à 50 périodes. Ce maximum est atteint après un temps :

$$
\begin{aligned}
\mathrm{T} & =0,995 \times 0,80 \times 0,73 \times 1,75 \\
& =1 \text { seconde environ }
\end{aligned}
$$

Il serait évidemment très intéressant de pouvoir évaluer approximativement l'écart maxinum de la vitesse de rotation à partir de nos graphiques, c'est-à-dire en sachant la valeur de I et de . En effet, la période des oscillations entretenues sur la frontière de la zone de stabilité ćtant donnée par : $2 \pi / \%$ en variables réduites, on pourrait espérer aboutir à une formule semblable à celle proposée pour les turbines Francis [8] :

$$
\begin{aligned}
u_{\max } & =\beta \sqrt{\mathrm{I} / t_{u}} \\
& =\beta \sqrt{2} \frac{\mathrm{q} / \pi}{\mathrm{i} / \pi}
\end{aligned}
$$

Dans le cas présent, il faudrait une valeur de égale à

$$
1,51
$$

pour que $\beta=1$. C'est à peu près le double de la valeur $\varphi=0,80$ qui correspond à $\lambda=0,50$ sur la frontière de la zone de stabilité pour $a=0,145$, $p=0,458$; l'équation (14) permet de contrôler ce chiffre trouvé par interpolation dans nos graphiques. L'étude de la variation de $\beta$ en fonction de o pour le $\lambda$ du régleur choisi ferait évidemment un sujet de recherche d'un très grand intérêt. 